DOI: $10.17516 / 1997-1370-0587$

УДК 332.1

\title{
Russian Economy as a Pyramid of Wealth Enclaves: Political Economy Approach
}

\author{
Sergey N. Levin and Kirill S. Sablin* \\ Kemerovo State University \\ Kemerovo, Russian Federation
}

Received 28.11.2019, received in revised form 03.03.2020, accepted 10.04.2020

\begin{abstract}
The article highlights the resource-industrial and institutional conditions causing the fragmentation of the economic space in Russia. In these conditions, the integration of the economy and society is ensured through the integrated political-administrative market of the centralized type. As a result, the functioning and development of the Russian economy are described as a complicated interweaving of the horizontal added value chains and the vertical chains of value redistribution. This created the pyramid of wealth enclaves in the Russian economy. The interaction between the actors controlling these enclaves occurs mainly on the political-administrative market, connected with the vertical redistribution of added value. The theoretical basis of the study is J. Stiglitz's model of dual enclave economy and the modified tools of the concept of global value chains (GVC). The study operates such qualitative research methods as conceptualization and comprehensive analysis. The study revealed that in the Russian economy the economic market fragmentation situation is persistently present. The pyramid of wealth enclaves linked with the vertical chains of value redistribution does not create incentives for the integrated development of the national economy.
\end{abstract}

Keywords: enclaves of wealth, economic market, political-administrative market, horizontal added value chains, vertical chains of value redistribution.

This research is supported by the Russian Foundation for Basic Research (RFBR), Grant No. 19-010-00244 "Institutional setup of the labour market in resource-type regions".

Research area: economics.

Citation: Levin, S.N., Sablin, K.S. (2020). Russian economy as a pyramid of wealth enclaves: political economy approach. J. Sib. Fed. Univ. Humanit. Soc. Sci., 13(4), 538-546. DOI: 10.17516/1997-13700587 .

\footnotetext{
(C) Siberian Federal University. All rights reserved

* Corresponding author E-mail address: sablin_ks@mail.ru ORCID: 0000-0002-5478-7481 (Sablin)
} 


\section{Introduction}

The problem of the enclaves of wealth hardly connected with the rest of the national economy was introduced by J. Stiglitz as a part of the dual enclave economy concept (Stiglitz, 2002). He noted that incorporation of the emerging market countries into the global economy did not result in their integrated development, but caused the emergence of the enclaves of wealth. These enclaves of wealth were mainly represented by the export enterprises controlled by foreign capital and privileged local business entities, practically disconnected from the rest of the economy. As a rule, these enclaves of wealth are represented by the resource exporting sector (mainly natural and mineral resources). The author emphasized the fact that these enclaves of wealth do not create incentives for the modernization of the other sectors of the national economy, but they serve as a source of financial resources for the public programs for implementation of the projects intended to develop other sectors of the economy and invest in human capital and social infrastructure. At the same time, the question about the methods and results of attracting and using these financial resources by the state remains open.

The distinctive feature of modern Russia making it different from the other countries with emerging markets is in the following:

1. Enclaves of wealth are controlled by the national state-owned companies, private companies and business groups affiliated with the state, but not by multinationals (Pappe, 2000; Pappe, Galukhina, 2009). This fact makes a direct impact on the employed ways of collecting and using the resources for the implementation of the development project initiated by the state.

2. The resource exporting enclaves of wealth are incorporated into a specific system distinguished with a complicated interweaving of the horizontal added value chains and the vertical chains of value redistribution. The centralized redistribution of financial resources creates some additional enclaves of wealth, defined as secondary and tertiary concerning the primary resource exporting enclaves of wealth.
This article discusses the institutional foundations of the system built in the context of the economic fragmentation and political-administrative centralization. As a result, the Russian economy does not emerge as an integrated market economy but appears as a fragmented economic space. The central element of a fragmented economic space is the pyramid of primary, secondary and tertiary enclaves of wealth. At the same time, the rest of the economy operates in the survival mode, having no sufficient economic and/or political resources to support its competitiveness and sustainable development capacity.

\section{Theoretical framework}

The study develops the approaches that formed the basics of the J. Stiglitz concept of enclave dual economy. The approaches of $\mathrm{J}$. Stiglitz are integrated with the models based on the new political economy. In contrast to the basic models of the public choice theory (Buchanan, Brennan, 2008), the political markets are studied in the broad sense, and various discrete structural alternatives of their organization are highlighted (Williamson, 1991; Levin, 2014; Levin, Sablin, 2018). From our point of view, considering the institutional system of Russia from the position of an inextricable relationship between economic and political institutions, a spectrum of discrete structural alternatives should be also taken into account. The factors determining the choice between these discrete structural alternatives are set by the fact of previous historical development (path dependence). The widely recognized features of the existing institutional system of Russia are the following: the coalescence of economy and politics; limited political and economic competition; the key role of state-owned companies and private business groups and companies affiliated with the state in the economy; vertical power structure with the federal centre enforcing the political and economic control over the regions.

In this regard, the question that arises is the objective economic foundations of the existing institutional system of Russia, its main elements, limitations and development prospects. From our point of view, this 
system is based on a historically determined relationship between the resource-industrial structure of the economy and the institutional organization of the economy and society. This means that the existing institutional system of Russia implies a certain type of relationship between the economy and the politics, the coalescence and limited real autonomy of these subsystems of society. The path dependence (Arthur, 1994; David, 2007) is revealed in the formed system of interactions between the resource-industrial and the political-economic structures of Russian society. This system forms the basic parameters of the institutional organization and creates a set of constraints for implementation of the economic modernization projects. Moreover, these constraints are quite strict. This means that, if the objective constraints are not taken into account when implementing any institutional projects, the lock-in effect is clearly revealed, returning the institutional system to the historically given development path. This fact was obvious during the post-Soviet economic and social development. The institutional project, implemented since the early 1990 -s, was focused on the separation of economy and politics, development of economic and political competition, as well as shaping a market-type institution system in the economy and creating political democracy. However, it resulted in the transformation of the Soviet system of administrative markets (Kordonskiy, 2006) into the system based on the dominance of the hybrid political-administrative market. Within this system, the coalescence of economy and politics was revived in a new form, and instead of separating private and public property, a hybrid system of real residual property rights was made up (Grossman and Hart, 1986; Levin, Sablin, Kagan, 2017).

\section{Statement of the problem}

The pyramid of the enclaves of wealth is formed as the Russian economy and society are developing between the poles of economic fragmentation and political-administrative centralization. Combined, the transformation of the domestic market and the integration of the economy into global markets caused the competitiveness of a narrow group of industries and companies within the resource exporting sector. This resulted in the lack of a domestic integrated and self-regulatory system of competitive markets for resources, goods and services in modern Russia. Therefore, the economic markets in Russia are disintegrated. Russian companies and business-groups compete on segregated global and domestic markets.

In these conditions, the economy and society in the country are integrated by the political-administrative market. In Russia, an integrated political-administrative market of centralized type has developed, with the ruling group being the ultimate source of the political resource. At the same time, within the framework of the unified vertical of power, some administrative, and, to a lesser extent, political bargaining takes place. The domestic business is incorporated into various levels of this vertical of power. As a result, the disintegrated economic markets in Russia are interwoven with the centralized and integrated political-administrative market. The relationship between the actors of these markets develops in two ways. Firstly, the availability of an individual political resource within the vertical of power is a factor for access to the most significant economic resources that determine the competitiveness of Russian companies, both on domestic and global economic markets. Secondly, in many cases, the actors of the political-administrative market either substitute the actors of the economic markets acting as the main "consumers" of goods and services of the domestic companies directly, or they determine the range of solvent "consumers" through the mechanisms of redistribution and centralization of revenues in favour of certain social groups and territories. Based on the position in this system, the authors of the article identify primary, secondary and tertiary enclaves of wealth.

\section{Methods}

To identify and characterize the enclaves of wealth, the tools of the global value chains (GVC) concept (Humphrey, Schmitz, 2001; Gereffi, Humphrey, Sturgeon, 2005) are used. 
This approach is adjusted to the presence of the centralized vertical chains of value redistribution within the vertical of power besides the horizontal value chains. In the context of this approach, Russian entrepreneurs are seen as actors that bring their interests into practice in the interwoven political-administrative and economic markets. At the same time, the political resource provided by the access to the political-administrative market, on the one hand, acts as a source of competitive advantages in economic markets, and, on the other hand, involves entrepreneurs taking a wide range of quasi-public obligations in the form of quasi-fiscal payments including quasi-tax fees and organized sponsorship (Levin, Kurbatova, 2011).

The authors also use a qualitative approach that involves conceptualization and comprehensive analysis of the problems of the formation and development of the enclaves of wealth in today's Russian economy.

\section{Discussion}

The basis of the Russian economy is formed by the resource exporting sector, which is the key source of revenues scraped from the global economic markets. As a result, Russian business groups and companies of this sector are the ones to form the primary enclaves of wealth. In this case, the access to the political-administrative market and availability of individual political resource allows them to monopolize the access to natural and mineral resources and establish favourable (preferable) individual conditions for the use of such. They sell their raw material products on the global economic markets being an important source of technologies and financial resources, especially in the context of today's sanctions.

The primary enclaves of wealth are enterprises, competitive on the global economic markets, representing mineral extraction and production industries manufacturing unfinished goods, controlled by the state-owned companies and state-affiliated private companies holding the significant political resources. These enclaves of wealth form the flows of income being the main source of profits for large businesses, as well as a source of fiscal and quasi-fiscal payments for the state. At the same time, the owners of these business groups take on quasi-public obligations to finance development projects in exchange for the political resource. At the moment, it is the financing system for national projects. The companies directly controlled by the state carry out most of the quasi-public obligations. For instance, in the year 2018, "Rosneft" Russian oil company implemented an extensive set of social programs including housing and mortgage lending, private pension programs, as well as improvement of the working and leisure conditions (Rosneft Annual Report, 2018). Taking up additional quasi-public obligations, "Rosneft" enjoys additional benefits from the state for the development of new hydrocarbon deposits in the shelf of the Arctic, Far Eastern and Southern Seas of Russia (Shel'fovye proekty, 2019), therefore increasing the commercial efficiency of "Rosneft".

Thus, the specificity of the position occupied by the domestic business groups that control the primary enclaves of wealth is a combination of exclusive advantages obtained due to their high position within the vertical of power with a rather strong competitive pressure within the global economy. In many cases, this creates quite powerful incentives for the modernization of the export-oriented resource industry. An example of such is a serious success in the technological modernization of the metallurgical (Gorbunov, 2013) and coal industries. Assessing the situation in the coal industry in Kuzbass, the head of one of the regional administration departments comments on it as follows: "Let's take the coal industry. In recent years, labour productivity in the coal industry of our country has significantly increased. You know that many coal industry enterprises are closing down today, and others are opening and modernizing. Compared to the Soviet years, the number of people employed in the coal industry has dropped by three times. At the same time, for example, the volume of 211 million tons was mined last year. In Soviet times, they dreamed of achieving the milestone of 160 million tons with a much larger number of employees. Now, the lion's share of this coal 
is being refined. In this sense, productivity inevitably increases" (Levin, Sablin, 2017: 43).

Business groups that control the primary enclaves of wealth do not only carry quasi-public obligations but also centralize revenues, redistributing them in favour of the central regions, primarily Moscow and St. Petersburg. It results in the development of high-margin consumer markets, serving as the economic basis for the emergence of the secondary (industrial) enclaves of wealth. At the same time, public funds are also concentrated in the centre. In this sense, we can speak of two interwoven chains of vertical value redistribution in favour of political-administrative and economic actors that occupy higher positions in the vertical of power.

The secondary (industrial) enclaves of wealth are sets of "semi-knocked down" (SKD) enterprises that serve as high-margin demand actors, generating their revenues due to the high status (direct or indirect) in the vertical of power. The high status opens access to the redistribution of value, created within the primary enclaves of wealth.

The most vivid example of a secondary industrial enclave of wealth is the development of the Kaluga regional economy. It became the benchmark of the region, whose authorities managed to build a balanced system of developmental institutions that ensured the implementation of large-scale investment projects in the manufacturing industry. At the first stage, the most significant success was associated with attracting foreign investments in the car assembly plants ("poorly diversified SKD"). In the future, it became possible to significantly diversify the sectoral structure of investments and increase the role of domestic investors (Skorobogaty, 2016). However, this enclave of wealth is still dependent on the injections of foreign technologies and investments. This makes it vulnerable in the face of the sanctions' pressure on the Russian economy.

The employment of political resources in the formation of such enclaves of wealth is closest to the practices of other foreign countries with emerging markets. The use of such new industrial policy tools may be demonstrated with the case of the Kaluga Oblast. Based on the incentives for car assembly plants initiated at the federal level, the regional authorities agreed with large foreign (and domestic) companies to implement a development project on transferring a part of the global horizontal value chain of the automotive industry to the region. The individual political resource of the regional authorities was used to gain support for this project from the federal authorities and developmental institutions. The enterprises included in this enclave of wealth mainly operate in the competitive domestic consumer markets. At the same time, the dynamics of demand in these markets depends on the state of the primary enclaves of wealth and the effect of vertical chains of value redistribution.

Having been put into practice, the public programs aimed at stimulating the development of innovations (Strategiia innovatsionnogo razvitiia $R F . . ., 2011)$ and reforming the scientific and educational complex of the Russian Federation (Proekt povysheniia konkurentosposobnosti..., 2012) caused the emergence of the tertiary (innovation and scientific-educational) enclaves of wealth. The most vivid examples are Skolkovo Research and Technology Centre and the Higher School of Economics (HSE). In this regard, it is necessary to highlight the paradox of the innovation development policy in modern Russia. Innovations were declared to be the main way of avoiding the resource exporting dependence and transiting to the "knowledge economy". However, the analysis shows that such structures as Skolkovo and HSE are the enclaves of wealth that are the most dependent on political-administrative market and the least focused on gaining competitive advantages in economic markets (at the level of real actions, not public declarations). The tertiary enclaves of wealth are dependent on the vertical chains of value redistribution in two ways.

Firstly, the establishment of such required large injections of public funds to give them access to the necessary resources including human capital. For example, in the years 2013-2015 Skolkovo Research and Technology Centre spent on its activities 65.5 billion roubles from the state budget ( $O$ rezul'tatakh kontrol'nogo..., 2016). HSE received an addi- 
tional investment of 860956 thousand roubles according to the Order of the Government of the Russian Federation in the year 2019 under the "Program 5-100" (Rasporiazhenie Pravitel'stva Rossiyskoy..., 2019).

Secondly, it is the state that acts as the main "consumer" of the R\&D, educational and expert services these structures create. They act mainly as suppliers of innovation, scientific and educational "semi-finished products" for the global innovation and scientific-educational sector (i.e. subcontractors of global innovative companies, undergraduates and doctoral students for universities in Europe and the USA, junior partners in international scientific networks).

At the same time, the preservation of even such competitive positions on the global economic markets seems to be very problematic without constant injections of public funds. The senior managers of these structures are well aware of this fact. In this regard, the assessment of the situation given by V. Kasama$\mathrm{ra}$, the HSE Vice-Rector, is a vivid example. Commenting on the statements about the need to preserve the university's autonomy from the state, she clearly expressed the position of the HSE leadership: "You know, to me, it seems to be somewhat childish to say that, keeping in mind that the HSE is a university under the Government of the Russian Federation and the Government is the founder of the HSE. We work with the Government and for the Government, and we are one of the consultants of the Government, but we are also the consultants for the other executive bodies and the Presidential Administration. It is very strange to oppose us" (Kasamara o slovakh Egora Zhukova pro sviaz..., 2019). These statements are true to life. HSE is funded not by hypothetical taxpayers acting in an ideal contract state $(\mathrm{Bu}-$ chanan, 1975), but by the ruling group. At the same time, being the top of the vertical chains of the value redistribution, the tertiary enclaves of wealth crown this pyramid.

\section{Conclusion}

The study confirms the hypothesis that there is no integrated system of autonomous and self-regulating economic markets in today's Russia. Economic markets are fragmented, and the conditions for their functioning are determined by the constraints of the integrated political-administrative market of centralized type.

As a result, the functioning and development of the Russian economy are determined by the complicated interweaving of the horizontal added value chains and the vertical chains of value redistribution. The core of the modern Russian economy is formed by the pyramid of enclaves of wealth: primary (resource exporting), secondary (industrial) and tertiary (innovation and scientific-educational). Competitiveness of the actors of these enclaves of wealth is based on the relationship between economic and political resources.

The political resource is the key factor for monopolizing access to the natural and mineral resources in the primary enclaves of wealth, and value is created in the competition on the global economic markets. The secondary industrial enclaves of wealth are focused on high-marginal domestic consumer markets. Their relationship with the primary enclaves of wealth is determined by the availability of a mechanism for the vertical redistribution of revenues in the favour of social groups and territories holding a high status in the vertical of power. The most paradoxical is the situation with the tertiary enclaves of wealth. According to the declared goals, the development of innovation and scientific-educational sectors was to decrease the degree the resource exporting dependence. However, these enclaves of wealth are based not on the added value creation, but mainly on the redistribution of value within the vertical of power. The state acts both as a source of financial resources and as the main "consumer" of their services.

\section{References}

Arthur, W. (1994). Increasing Returns and Path Dependence in the Economy. Ann Arbor: University of Michigan Press. 
Buchanan, J. (1975). The Limits of Liberty: Between Anarchy and Leviathan. Chicago: University of Chicago Press.

Buchanan, J., Brennan, G. (2008). The Reason of Rules: Constitutional Political Economy. Cambridge: Cambridge University Press.

David, P. (2007). Path Dependence: A Foundational Concept for Historical Social Science. In Cliometrica, 1(2), 91-114.

Gereffi, G., Humphrey, J., Sturgeon, T. (2005). The Governance of Global Value Chains. In Review of International Political Economy, 12(1), 78-104.

Gorbunov, A. (2013). Truby bez komissii [Pipes Without Commission]. In Expert, 25(856).

Grossman, S.J., Hart, O.D. (1986). The Costs and Benefits of Ownership: A Theory of Vertical and Lateral Integration. In Journal of Political Economy, 4, 691-719.

Humphrey, J., Schmitz, H. (2001). Governance in Global Value Chains. In IDS Bulletin, 32(3), 19-29.

Kasamara o slovakh Egora Zhukova pro sviaz' VShE s gosudarstvom: eto po-detski [Kasamara about the Words of Yegor Zhukov about the Relationship of HSE with the State: It's Childish] (2019). Available at: https://russian.rt.com/russia/news/696719-kasamara-zhukov-vshe (accessed 24 February 2020).

Kordonskiy, S.G. (2006). Rynki vlasti. Administrativnye rynki SSSR i Rossii [Markets of Power. Administrative Markets of the USSR and Russia]. Moscow: OGI.

Levin, S.N. (2014). Rynki vlasti, rezhimy prav sobstvennosti i politicheskiy resurs predprinimateley v sovremennoy Rossii [Markets of Power, Property Rights Regimes and Political Resource of Entrepreneurs in the Modern Russia]. In Mir Rossii [Universe of Russia], 23(4), 35-58.

Levin, S.N., Kurbatova, M.V. (2011). Setevye vzaimodeystviia rossiyskogo biznesa: delovaia korruptsiia i organicheskiy institut real'noy modeli institutsional'noy organizatsii rossiyskoy ekonomiki [Network Relationships of the Russian Business: Business Corruption and the Organic Institute of the Real Model of Institutional Organization of the Russian Economy]. In Journal of Institutional Studies, 3(2), 39-58.

Levin, S.N., Sablin, K.S. (2017). "Politicized" Bureaucrats as Agents of Economic Development in Resource-Rich Regions. In Social Sciences, 48(1), 35-47. DOI: 10.21557/SSC.48463650

Levin, S.N., Sablin, K.S. (2018). Kontseptsiia rynkov vlasti kak metodologiia issledovaniia institutsional'noy organizatsii sovremennoy rossiyskoy ekonomiki i obshchestva [The Concept of the Power Markets as a Methodology to Study Modern Russian Economy and Society Institutional Organization]. In Journal of Institutional Studies, 10(4), 97-111. DOI: 10.17835/2076-6297.2018.10.4.097-111

Levin, S.N., Sablin, K.S., Kagan, E.S. (2017). Za predelami stekliannogo kolpaka: innovatsionnoe predprinimatel'stvo v regionakh resursnogo tipa v Rossii [Beyond Bell Jar: Innovative Entrepreneurship in Resource-Type Regions of Russia]. In Journal of Institutional Studies, 9(3), 119-132. DOI: 10.17835/20766297.2017.9.3.119-132

O rezul'tatakh kontrol'nogo meropriiatiia "Proverka ispol'zovaniia sredstv federal'nogo biudzheta, napravlennykh na realizatsiiu meropriiatiy, sviazannykh s sozdaniem i obespecheniem funktsionirovaniia innovatsionnogo tsentra "Skolkovo" $v$ 2013-2015 godakh» (sovmestno s Federal'noy sluzhboy bezopasnosti Rossiyskoy Federatsii [About the Results of the Control Event "Verification of the Use of Federal Budget Funds aimed at Implementing Measures Related to the Creation and Maintenance of Skolkovo Innovation Centre in 2013-2015" (in cooperation with the Federal Security Service of the Russian Federation)] (2016). Available at: http://audit.gov.ru/upload/iblock/1e6/1e665e7c4e51f8357188a9508f7cc847.pdf (accessed 20 February 2020).

Pappe, Y.Sh., Galukhina, Y.S. (2009). Rossiiskiy krupnyy biznes: pervye 15 let. Ekonomicheskie khroniki 1993-2008 [Russian Big Business: First 15 years. Economic Chronicles 1993-2008]. Moscow: Publishing House of the Higher School of Economics.

Pappe, Y.Sh. (2000). "Oligarkhi”. Ekonomicheskaia khronika 1992-2000 ["Oligarchs". Economic Chronicles 1992-2000]. Moscow: Publishing House of the Higher School of Economics.

Proekt povysheniia konkurentosposobnosti vedushchikh rossiyskikh universitetov sredi vedushchikh mirovykh nauchno-obrazovatel'nykh tsentrov "5-100" [Project of Increasing the Competitiveness of the Top Russian Universities among the World's Leading Research and Educational Centres 
“5-100”] (2012). Available at: https://www.5top100.ru/documents/regulations/97332/ (accessed 20 February 2020).

Rasporiazhenie Pravitel'stva Rossiyskoy Federatsii ot 9 fevralia 2019 g. № 179-r o raspredelenii subsidiy vedushchim universitetam $v$ tseliah povysheniia ikh mezhdunarodnoy konkurentosposobnosti [Order of the Government of the Russian Federation No. 179-r on the Distribution of Subsidies to the Leading Universities in Order to Increase their International Competitiveness] (2019). Available at: https://www.5top100.ru/documents/regulations/97332/, accessed 20 February 2020.

Rosneft Annual Report 2018. Technologies Shaping the Future (2018). Available at: https://www.rosneft.com/Investors/Reports_and_presentations/(accessed 18 February 2020).

Shel'fovye proekty [Shelf Projects] (2019). Available at: https://www.rosneft.ru/business/Upstream/ offshore/ (accessed 17 February 2020).

Skorobogaty, P. (2016). Kaluga: ot avtosborki k klasternoy diversifikatsii [Kaluga: from Automotive Assembly to Cluster Diversification]. In Expert, 24(991).

Stiglitz, J. (2002). Globalization and Its Discontents. New York: W.W. Norton \& Co.

Strategiia innovatsionnogo razvitiia $R F$ na period do 2020 goda [Strategy of the Innovative Development of the RF till 2020] (2011). Available at: http://government.ru/docs/9282/ (accessed 20 February 2020).

Williamson, O. (1991). Comparative Economic Organization: The Analysis of Discrete Structural Alternatives. In Administrative Science Quarterly, 36, 269-296. 


\title{
Российская экономика
}

\section{как пирамида анклавов богатства: \\ политико-экономический подход}

\section{С.Н.Левин, К.С. Саблин}

Кемеровский государственный университет

Российкая Федерация, Кемерово

\begin{abstract}
Аннотация. В исследовании рассматриваются ресурсно-отраслевые и институциональные условия, ведущие к фрагментации экономического пространства России. В этих условиях интеграция экономики и социума обеспечивается политико-административным рынком централизованного типа. В результате функционирование и развитие российской экономики характеризуются сложным переплетением горизонтальных цепочек создания стоимости и вертикальных цепочек ее перераспределения. Это привело к появлению в российской экономике пирамиды анклавов богатства. Взаимодействие между субъектами, контролирующими эти анклавы, осуществляется преимущественно на политико-административном рынке и связано с вертикальным перераспределением стоимости. Теоретической основой исследования является модель анклавной двойственной экономики Дж. Стиглица и модифицированный инструментарий концепции глобальных цепочек создания стоимости. В работе используются качественные методы исследования концептуализация и комплексный анализ. Проведенное исследование показало, что в экономике России устойчиво сохраняется ситуация фрагментации экономических рынков, а связанная цепочками перераспределения стоимости пирамида анклавов богатства не создает стимулов для целостного развития национальной экономики.
\end{abstract}

Ключевые слова: анклавы богатства, экономический рынок, политикоадминистративный рынок, горизонтальные цепочки создания стоимости, вертикальные цепочки перераспределения стоимости.

Грант РФФИ № 19-010-00244 «Институциональная организация рынка труда в регионах ресурсного типа».

Научная специальность: 08.00.00 - экономические науки. 